\title{
Application of a Crescent-Shaped PMMA Strut in Anterior Spinal Reconstruction of Thoracolumbar and Lumbar Burst Fractures: A New Technique
}

\author{
Torakolomber ve Lomber Fraktürü Olan Hastalarda \\ Polimetilmetakrilattan Yapılma Hilal Şeklindeki Enstrümanın \\ Uygulanmasi: Yeni Bir Teknik
}

\author{
Wan JUN ${ }^{1}$, Kang YI-JUN² ${ }^{2}$ Chen FEI ${ }^{2}$ \\ ${ }^{1}$ Xiangya Hospital, Central South University, Department of Orthopedics, Changsha, China \\ ${ }^{2}$ Xiangya Second Hospital, Central South University, Department of Spine Surgery, Changsha, China \\ Correspondence address: Kang YI-JUN / E-mail: f2kangyijun@163.com
}

\begin{abstract}
AIM: Our aim was to evaluate the safety and efficacy of the novel crescent-shaped PMMA strut for anterior spinal reconstruction and fusion in patients with thoracolumbar bust fractures. The surgical results using this technique are reviewed.

MATERIAL and METHODS: Six patients suffering thoracolumbar and lumbar fracture using a crescent-shaped PMMA strut combined with fixation for reconstruction of the anterior spinal column. Postoperative radiographic, included plain x-ray and 3-D computed tomography (CT) imaging, evaluated fusion status postoperatively. Pain relief and neurological status was assessed by comparing Frankel Score and Vision Analogue Score (VAS) pre- and postoperatively.

RESULTS: All six patients achieved immediate stabilization. No patient needs additional posterior instrumentation stabilization due to loss of sagittal alignment and kyphosis deformity. All patients achieved significant relief of back pain, improvement of neurological function, correction of preoperative deformity and excellent bone fusion results documented on plain x-rays and 3-D CT reconstruction imaging. There were no complications of neurological worsening, wound infection, subsidence and dislodgement of PMMA strut, or anterior instrumentation failure during the follow-up.

CONCLUSION: The crescent-shaped PMMA strut is an alternative for anterior spinal reconstruction and fusion in patients with thoracolumbar burst fracture. However, the long-term clinical effects and possible complications need further evaluation.
\end{abstract}

KEYWORDS: Burst fracture, Polymethylmethacrylate, Crescent-shaped, Anterior reconstruction

öz

AMAÇ: Torakolomber bölgede patlama kırığı olan hastalarda rekonstrüksiyonu ve füzyonu sağlamak için kullanılan polimetilmetakrilattan yapılma, hilal şeklinde olan yapının etkinliğinin ve güvenilirliğinin saptanması için bu tekniğin kullanıldığı hastaların cerrahi sonuçlarının ortaya konması.

YÖNTEM ve GEREÇLER: Polimetilmetakrilattan yapılma, hilal şeklindeki enstrüman, torakolomber bölgede patlama kırığı olan 6 hastada anterior kolonun rekonstrüksiyonunu ve füzyonunu sağlamak için kullanılmıştı; bu hastalara aynı zamanda stabilizasyon işlemi de yapıılmıştır. Radyolojik olarak; düz grafiler ve 3 boyutlu bilgisayarlı tomografilerle füzyon ve rekonstrüksiyon gelişimi incelenmiştir. Ayrıca tüm hastalara ameliyat öncesi ve sonrası dönemde Frankel ölçütlemesi ve Görsel ağrı ölçütlemesi yapılmıştır.

BULGULAR: Tüm hastalarda erken dönemde stabilizasyon gerçekleşmiştir. Hastaların hiçbirinde sagital plan bozulması ve kifoz gelişimi olmamıştır, bu nedenle fazladan bir posterior stabilizasyona gerek duyulmamıştır. Üç boyutlu bilgisayarlı tomografi ve normal x-ray grafilerinde hastalarda mükemmel füzyon geliştiği ve deformitelerinin düzeldiği görüldü; bunun yanı sıra, hastaların hepsinde bel ağrısı geçti, nörolojik fonksiyonları daha iyi hale geldi. Hastalarda nörolojik kötüleşme, Polimetilmetakrilattan yapılma hilal şeklindeki enstrümanın gömülmesi ya da uzerinde çıkması, yara infeksiyonu ve anterior enstrümanın yetmezliği gibi bir durum gelişmedi.

SONUÇ: Torakolomber bölgede patlama kırı̆ı̆ı olan hastalarda rekonstrüksiyonu ve füzyonu sağlamak için kullanılan polimetilmetakrilattan yapılma, hilal şeklinde olan enstrüman anterior spinal rekonstrüksiyona ve füzyona alternatif bir yöntemdir; ancak, uzun süreli klinik etkilerinin ve komplikasyonlarının ortaya konması için daha fazla çalışma yapılması gereklidir.

ANAHTAR SÖZCÜKLER: Patlama kırığı, Polimetilmetakrilat, Hilal- şekli, Anterior rekonstrüksiyon 


\section{INTRODUCTION}

Compression failure of both the anterior and the middle columns can cause burst fracture under axial loads $(11,31)$. The optimal approach to treat burst fractures remains controversial $(7,23,24,27)$. Surgical decompression and stabilization in cases with incomplete neurological compromise has been widely advocated in recent years. Surgical intervention can immediately relieve pain, optimize neural decompression, provide quick spinal stability and avoid kyphotic deformity with stable internal fixation over the least number of spinal segments $(8,28)$.

The optimal strategy of surgery (anterior, posterior, or combined approaches) is still a matter of debate $(8,25$, 28). There are many factors which determine the chosen treatment, such as the age of the patients, neurological status of the patients, degree of osteoligamentous structure instability, the experience of the surgeons and so on. Compared with posterior approach, anterior reconstruction with instrumentation allows restoration of the mechanical integrity of the anterior column, direct decompression of the spinal canal and direct removal of damaged discs; furthermore it has a theoretical better rate of fusion $(16,19,29,32)$.

Anterior reconstruction and the fusion of defect spine resulted from burst fracture of vertebral can be achieved by placing autografts like tricortical iliac crests or allografts, or titanium mesh cages $(9,12,17,18,21,22)$. According to the previous reports (17), the incidence of donor-site morbidity is high when autografts were used. Postoperative morbidity of donor-site can be reduced by using allografts. It can also achieve uniformly strong cortical and cancellous bone with unlimited choices of grafts shape and sizes, and shorten the operation time. However, longer fusion times and immunologic rejecting reaction by the host was observed when using allografts. It may cause the possibility of transmission of diseases (18) and it is hard to obtain the allografts because of the social customs in China.

Due to the better biocompatibility and biomechanical resistance to axial loading forces, the titanium mesh cage, as a recent vertebral prosthesis, is widely used in recent years $(9$, $12,22)$. However, it is difficult to evaluate the fusion status when titanium mesh cage was used $(13,14)$. Moreover, the high price of titanium mesh cage limits its widely clinical application.

The PMMA strut has been used clinically in many medical centers for treating cervical vertebral diseases $(3-6,15,20$, 26). However, there is no clinical report on using PMMA strut in anterior spinal reconstruction when dealing with thoracolumbar and lumbar burst fracture.

Under the circumstance mentioned above, we designed a novel crescent-shaped PMMA strut in order to provide a new alternative for anterior spinal reconstruction. The article is aimed to evaluate the safety and efficacy of the novel crescent-shaped PMMA strut for anterior spinal reconstruction and fusion in patients with thoracolumbar and lumbar burst fractures.

\section{CLINICAL MATERIAL and METHODS}

\section{Patient Population}

From January 2004 to December 2007, 6 patients who had a single-level thoracolumbar or lumbar burst facture accepted surgical intervention with anterior spinal reconstruction using self-made crescent-shaped PMMA strut combining with an anterior inner fixation (Ventrofix, Synthes Inc. Company, U.S.A). The inclusion criteria specified a single-level Denis type $A, B$, or C bust fracture of the thoracolumbar or lumbar spine (1). The patient population consisted of four women and two men whose ages ranged from 25 to 62 (mean $42.8 \mathrm{yr}$ ). All the 6 patients have complaint of back pain and different degree of neurological deficit at the time of hospitalization (details described at Table I). Preoperative imaging, including plain x-rays, CT (computed tomography) or MRI (magnetic resonance imaging), revealed thoracolumbar or lumbar burst fracture in the 6 patients (Figure $3 A, B$ ). One patient (patient 3 ), injured 3-months ago, performed the first posterior pedicle screw fixation in another hospital but had little improvement of his symptoms. Preoperative plain $\mathrm{x}$-ray imaging revealed incomplete restoration of vertebrae height and partial compression of the spinal cord.

\section{Production of PMMA Strut}

Considering many different factors, we design a novel crescent-shaped PMMA strut which can be made easily in operation room. The materials we need are only two elements: PMMA (Polymethylmethacrylate) bone cement and two syringes (one's volume $50 \mathrm{ml}$ and the other's $20 \mathrm{ml}$ ).

Firstly the length of $50 \mathrm{ml}$ syringe was modified equally to the measured sagittal length of reconstruction area (Figure 1A), then the $20 \mathrm{ml}$ one was put into the $50 \mathrm{ml}$ one with one edge attached together (Figure 1B). In the period of wiredrawing phase, the bone cement (PMMA) was pressed into the space between the two syringes as much as possible and waited for the hardening (Figure $1 C, D$ ). Finally the crescent-shaped PMMA strut was made successfully by getting rid of the syringe tubes (Figure 1E,F).

\section{Surgical Technique}

All the surgery was performed in a single department by one experienced surgeon. All patients were performed under general endotracheal anesthesia with the retropleural or transthoracic approach used for the thoracic region and the retroperitoneal approach for the thoracolumbar and lumbar region. Normally, the approach was from the left side due to consideration of avoidance of unexpected injury of abdominal aorta and inferior vena cava and convenience for the operation of the surgeon. After exposure of surgical field, segment vessels were carefully ligated. Then fractured vertebral body and damaged discs were identified and resected with curettes, rongeurs. After resection of the burst fractural vertebral body and preparation of its end plates above and below by using a high speed air-drill, the anterior inner fixation (Ventrofix, Synthes Inc Company, U.S.A) was place into the adjacent normal vertebral body to stabilize 
Table I: The Crescent-Shaped PMMA Strut Reconstruction in Six Patients

\begin{tabular}{|c|c|c|c|c|c|c|c|c|}
\hline $\begin{array}{c}\text { Patients } \\
\text { No }\end{array}$ & $\begin{array}{c}\text { Age } \\
\text { (yr/sex) }\end{array}$ & $\begin{array}{c}\text { location (pre/post) } \\
\text { Outcome }\end{array}$ & $\begin{array}{c}\text { VAS } \\
\text { (mo) }\end{array}$ & $\begin{array}{c}\text { Neurological } \\
\text { outcome }\end{array}$ & $\begin{array}{c}\text { Complication } \\
\text { Angle }\left({ }^{\circ}\right)\end{array}$ & $\begin{array}{c}\text { Follow-up } \\
\text { (per/post) }\end{array}$ & $\begin{array}{c}\text { Fusion } \\
\text { (per/post) }\end{array}$ & $\begin{array}{c}\text { Segmental } \\
\text { (peg }\end{array}$ \\
\hline 1 & $62 / M$ & T12 & $7 / 2$ & D/E & None & 24 & Good & $27 / 3$ \\
\hline 2 & $42 / F$ & L3 & $6 / 2$ & D/E & None & 18 & Good & $30 / 3$ \\
\hline 3 & $32 / M$ & T12 & $6 / 1$ & C/D & None & 18 & Good & $35 / 5$ \\
\hline 4 & 25/F & L1 & $6 / 1$ & D/E & None & 15 & Good & $34 / 3$ \\
\hline 5 & 55/F & L1 & $5 / 1$ & C/D & None & 18 & Good & $32 / 5$ \\
\hline 6 & 41/F & L3 & $5 / 1$ & D/E & None & 18 & Good & $37 / 6$ \\
\hline
\end{tabular}

M: male, F: female, Pre/post: preoperation/postoperation, VAS: Vision Analog Score. Neurological outcome measured by Frankel Scale. Mo: Month, Good: good growth of cancellous bone bridging the adjacent bodies showed in plain x-ray or 3-D CT reconstruction.
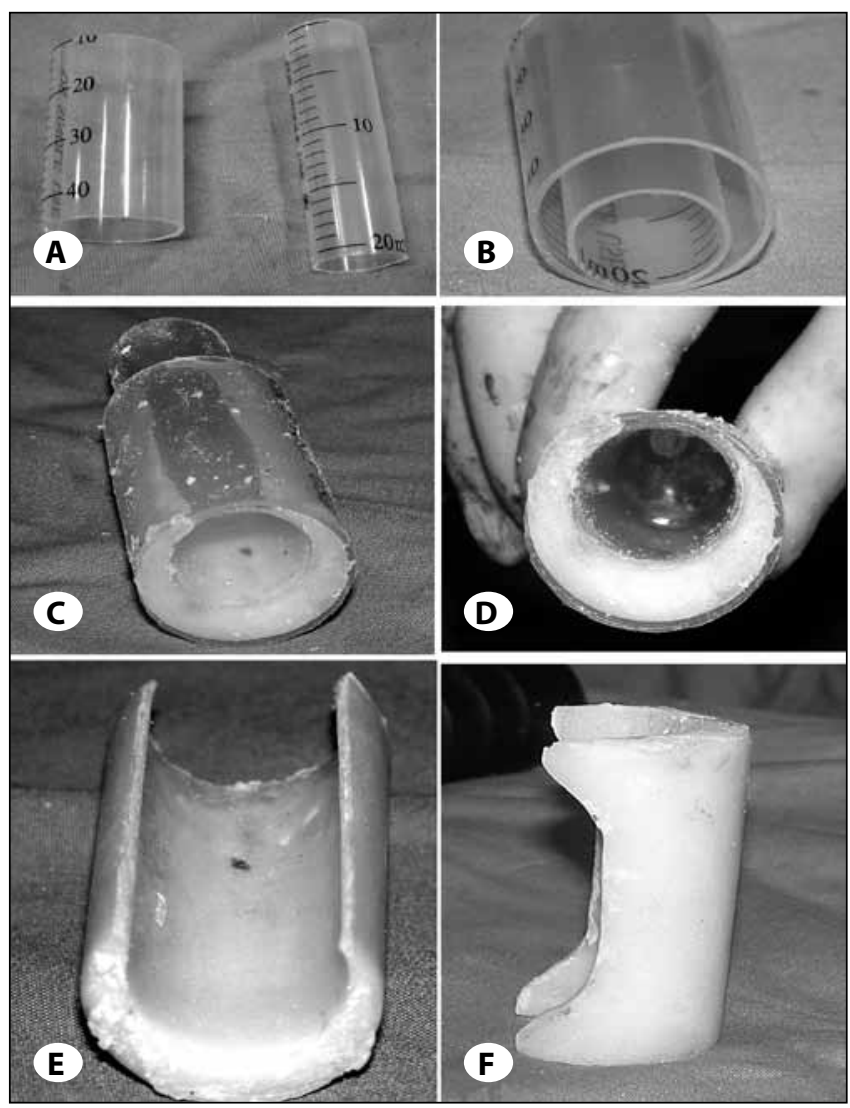

Figure 1: A) The Cresent-shaped PMMA strut was made intraoperatively in accordance with the same length of the defect area. B) The $20 \mathrm{ml}$ syringe was put into the $50 \mathrm{ml}$ syringe with one edge attached together. C,D) The bone cement (PMMA) was pressed into the space between the two syringes as much as possible and waited for the hardening. E,F) The crescent-shaped PMMA strut was made successfully.

the involved spine and performed appropriate distraction to correct the previous kyphosis caused by collapsed vertebral body. Then the sagittal length of defect area was measured. After production out of surgical field according to the same length previously measured, suitable-length crescent-shaped PMMA strut was put into the defect area combining with autogenous cacellous bone harvested from the fractured

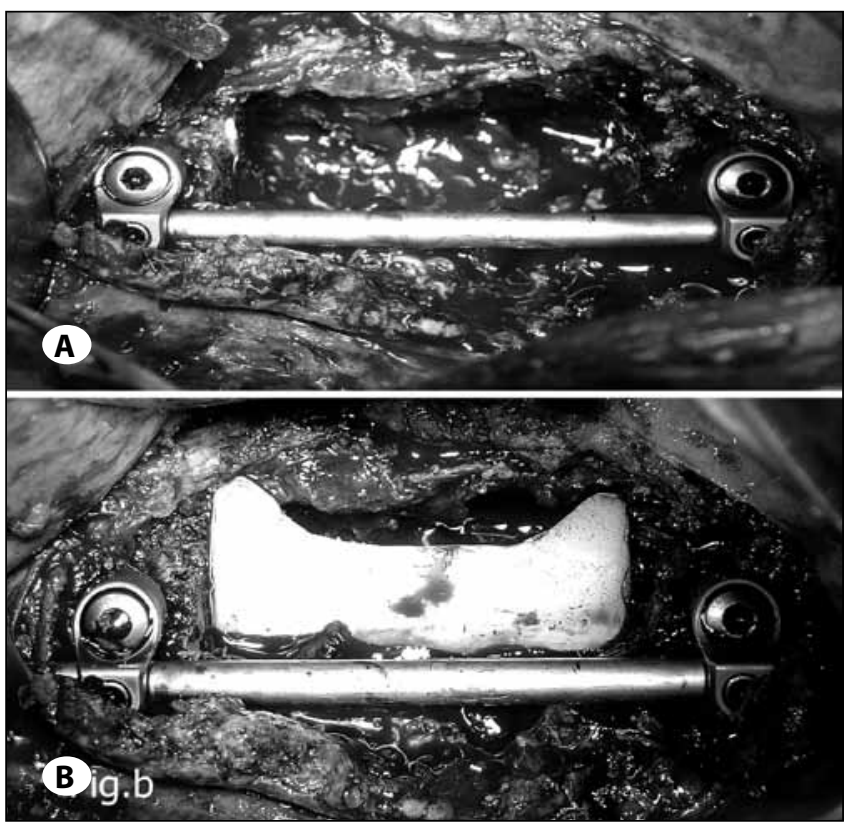

Figure 2: A) Preparation of placement of PMMA strut and B) placement of PMMA strut during the operation.

vertebral body. One point should be mentioned is that 'curve' of the 'crescent-shape' should be placed in front of the dural sac which can avoid the possibility of autogenous cancellous bone dropping back to compress the spinal cord (Figure 2A, $B)$. A wound drainage tube was inserted routinely before the closure of the wound. Closed drainage of the pleural cavity should be placed when a transthoracic approach was performed or pleura were torn open during the surgery. All the patients were instructed to use an external orthosis for immobilization respectively during the first 3-6 postoperative weeks till well-bridged cancellous bone between the adjacent vertebral bodies could be observed based on plain x-rays or 3-D CT imaging.

\section{Clinical outcomes and imaging follow-up}

All the 6 patients received regular check-ups at outpatient department of our hospital monthly for the first 3 months and then every 3 months thereafter. Neurological function was recorded at every visit. 


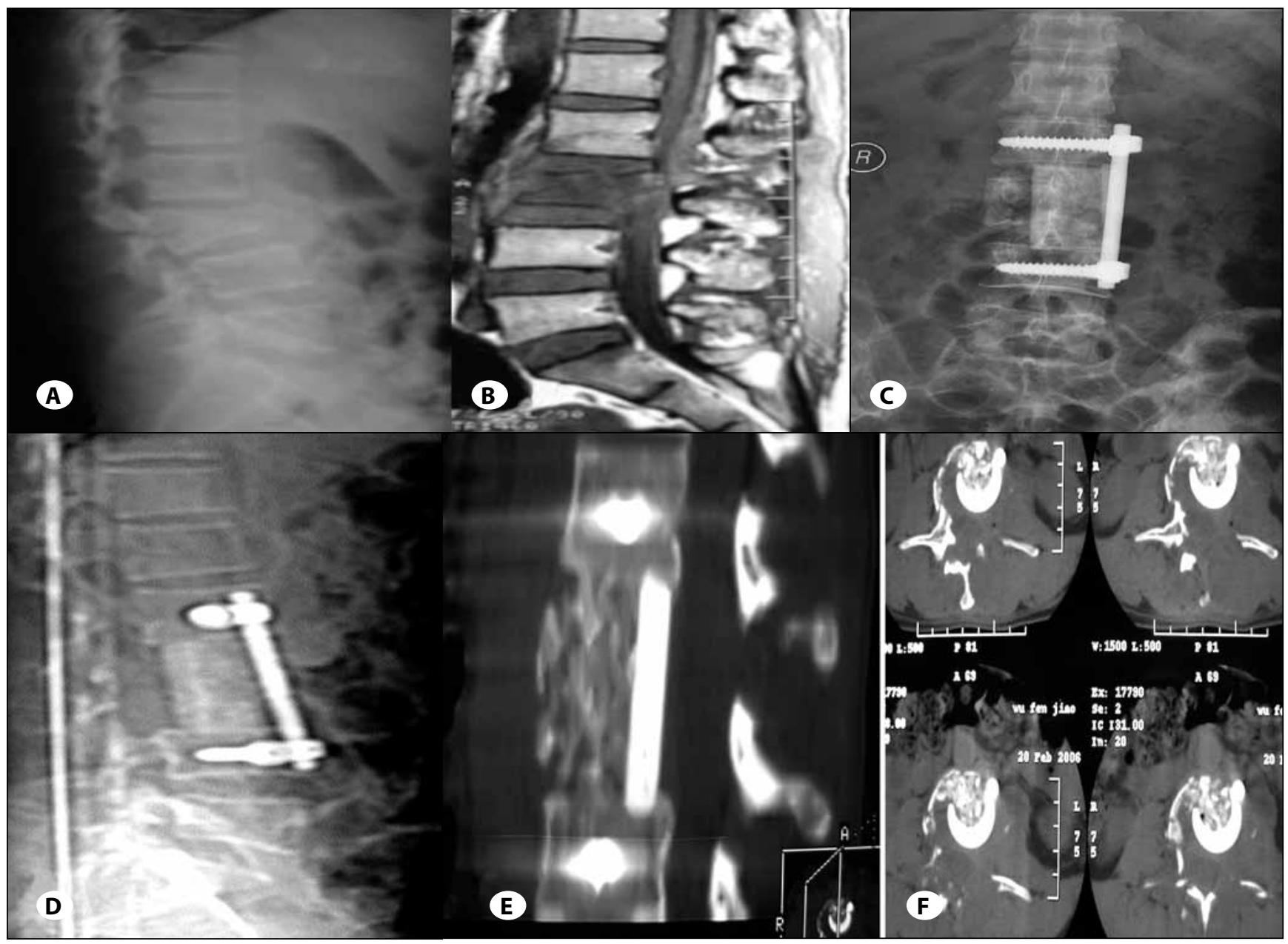

Figure 3: A 42-year-old female patient suffered L3 vertebral burst fracture caused in a car accident with neurological deficit of Frankel D. Preoperative plain x-ray (A) and MRI (B) showed the fracture of L3 vertebrae and compression on the spinal cord. Postoperative 14-month follow-up plain $x$-ray (C, D) presented good alignment achieved and complete decompression on the spinal cord. Postoperative 14-month follow-up sagittal (E) and axial (F) CT reconstruction revealed good cancellous bone growth in reconstruction area. Neurological deficit of the patient finally improved to Frankel $\mathrm{E}$.

Pain relief and neurological status was assessed by comparing Visual Analog Scale (VAS) and the Frankel Scale pre- and postoperatively.

The imaging follow-up included a plain X-ray imaging monthly for the first 3 months, and then every 3 months thereafter. Pre- and postoperative plain $\mathrm{x}$-rays were evaluated for correction of kyphotic deformity (Cobb's angle) and the fusion status. Radiographic fusion criteria included evidence of bridging bone formation observed on the plain $x$-rays or 3-D CT imaging (performed when evidence of bone fusion could not be clearly observed in the plain x-ray imaging).

\section{RESULTS}

The period of follow-up ranged from 15 to 24 months (mean, $17.5 \mathrm{mo}$ ). All the 6 patients achieved immediate stabilization. No patient needs additional posterior instrumentation stabilization due to loss of sagittal alignment (Figure 3C,D). All patients achieved significant relief of back pain (mean 4.5 evaluated by the VAS), improvement of neurological function (at least 1 class improvement evaluated by the Frankel Scale), correction of preoperative deformity (mean correction of Cobb's angle, $28.3^{\circ}$ ) and good bone fusion results documented on plain x-ray or 3-D CT reconstruction imaging (Figure 3E,F). There were no complications of neurological worsening, wound infection, subsidence and dislodgement of PMMA strut, or anterior instrumentation failure. (Details described in Table I)

\section{DISCUSSION}

When dealing with thoracolumbar and lumbar burst fracture through a surgical intervention, an anterior reconstruction technique is chosen because of the predictability of relieve compression with direct vision and the facility to directly reconstruct the spine $(16,19,29,32)$.

There are various bone grafts used in anterior spinal reconstruction to restore spinal alignment and stability. 
An ideal bone graft should have the properties including osteogenic, osteoconductive, osteoinductive, improving regenerative capacity of host bone and load-bearing. Bone grafts can be categorized as autografts, allografts, titanium mesh cages and PMMA struts in clinical application.

Based on experimental studies, vascularization and ossification of using autografts occur faster than using allografts. However, because of limitation in donor stock quality (shape and size) and increasing concerns about morbidity in the donor site, autografts are no longer the optimal choice when dealing with anterior spinal reconstruction (17).

The use of allografts avoids morbidity in donor site and shortens operative time. Despite of the unlimited bone shape and size, allografts can be added into autologous bone from the burst vertebral body. Disadvantages of using allografts include longer fusion times, immunologic rejecting reaction by the host, and risk of transmission of diseases such as Hepatitis and human immunodeficiency virus (18). Finally, appropriate allograft bone is not always available due to reasons like social custom and religion.

Recent reports on results of anterior spinal reconstruction with titanium mesh cages are promising $(9,12,22)$. However, one of the disadvantages of using titanium mesh cages was the difficulty of evaluating the status of fusion $(13,14)$. The other disadvantage preventing its clinical application was the high price, especially in the developing countries in which the health care system cannot cover all civilian.

PMMA bone cement has been used in revision of failed uncemented femoral components of total hip arthroplasty (10), enforcement of transpedicle screw fixation in patients with osteoporosis for decades (2). Despite of its rare complication such as bone cement leakage and pulmonary embolism, more clinical application of PMMA can be seen in vertebroplasty of osteoporotic vertebral fractures in recently years (30).

The PMMA strut has been used clinically in many medical centers mainly for treating cervical vertebral diseases (3-6, $15,20,26)$. Chen JF, et al. reported a case series of success application of PMMA strut in anterior spinal reconstruction including PMMA cages after one-level cervical discectomy in the treatment of patients with compressive monoradiculopathy and hollow cylindrical PMMA strut for spinal reconstruction after single-level cervical corpectomy $(5,6)$. They also used an antibiotic-PMMA strut for spinal reconstruction after anterior C5 and C6 corpectomy in one case with cervical pyogenic spondylitis and achieved satisfactory results after the 12-month follow-up (4). Pan $\mathrm{CH}$,et al., (20) described hollow bone cement filled with impacted cancellous bone as a substitute for bone grafts in cervical spine fusion. Good results were observed after mean 19-month follow-up of 21 patients performing the surgery.

We describe a technique using a crescent-shaped PMMA strut for anterior spinal reconstruction in patients with thoracolumbar burst fracture. To the best of our knowledge, this is the first report on using PMMA strut in anterior thoracolumbar reconstruction and fusion.

We made the crescent-shaped PMMA strut outside the field of operation which minimized the toxicity and the heat injury of PMMA. As a framework assisting the cancellous bone in connection with the two adjacent vertebral bodies, the complex folding of polymers of PMMA can postulate its collapse in body. Thus it is an advantage over autografts (20).

We design the PMMA strut as a crescent-shape for consideration that the main nutrition of cancellous bone came from plasma and tissue fluid after separation from blood supply, which can guarantee both the framework capability and enough space left allowing contact of cancellous bone with plasma and tissue fluid. It is also the highlight that, we think, is prior to the cylindrical-shaped PMMA strut (6) which absolutely separated cancellous bone from plasma and tissue fluid. Meanwhile, because its production was carried out totally during the operation, the length of PMMA strut is completely the same as the sagittal length of the defect area which is prior to preoperative production of PMMA strut according to indirect MRI imaging (6).

Postoperative plain x-ray or 3-D CT imaging revealed that the autologous cancellous bones migrated along the crescentshaped space surrounded by the PMMA bone cement and finally integrate into the end plate of the vertebral body, which meant good fusion result were achieved. The deformity correction achieved immediately were satisfactory postoperatively in our cases. (Figure 3) More important, deformity correction was maintained and no subsidence and dislodgement of antibiotic crescent-shaped PMMA strut was observed during follow-up.

We think the crescent-shaped PMMA strut has many advantages compared to other bone grafts: 1) It has the same property that can be made unlimited size as allografts and universally available. 2) It can provide the same framework effect as tricortical autografts without considering morbidity of donor site and has prolonged collapsing time in body. 3) Differentiating from Titanium mesh cages, the crescentshaped PMMA strut is composed of not metal but polymer materials which can display sufficient clarity the interface between the crescent-shaped PMMA strut and the vertebra when performing CT scanning (6). 4) Lower cost allows PMMA strut more appreciating in clinic application than Titanium mesh cages.

\section{CONCLUSION}

The crescent-shaped PMMA strut is an alternative for anterior spinal reconstruction and fusion in patients with thoracolumbar and lumbar burst fracture. The advantages include the universally available materials, ease of production and implementation during the operation, reduced morbidity at the donor site and low cost. However, the long-term clinical effects and possible complications need further evaluation. 


\section{ACKNOWLEDGEMENT}

We thank Miss Jing Wan for her editorial and secretarial assistance.

\section{REFERENCES}

1. Baurer TW, Muschier GF: Bone graft materials: An overview of the basic science. Clin Orthop 371:10-27, 2000

2. Becker S, Chavanne A, Spitaler R, Kropik K, Aigner N, Ogon $\mathrm{M}$, Redl $\mathrm{H}$ : Assessment of different screw augmentation techniques and screw designs in osteoporotic spines. Eur Spine J 17(11):1462-1469, 2008

3. Böker DK, Schultheiss R, Probst EM: Long-term results after cervical interbody fusion with polymethyl methacrylate (PMMA). Adv Neurosurg 18:49-54, 1990

4. Chen JF, Lee ST: Antibiotic-polymethylmethacrylate strut: An option for treating cervical pyogenic spondylitis. Case report. J Neurosurg Spine 5(1):90-95, 2006

5. Chen JF,WuCT,LeeSC, LeeST:Use of a polymethylmethacrylate cervical cage in the treatment of single-level cervical disc disease. J Neurosurg Spine 3:24-28, 2005

6. Chen JF, Wu CT, Lee SC, Lee ST: Hollow cylindrical polymethylmethacrylate strut for spinal reconstruction after single-level cervical corpectomy. J Neurosurg Spine 5(4): 287-293, 2006

7. Dai LY, Jiang LS, Jiang SD: Conservative treatment of thoracolumbar burst fractures: A long-term follow-up results with special reference to the Load Sharing Classification. Spine 33:2536-2544, 2008

8. Dai $L Y$, Jiang $S D$, Wang $X Y$, Jiang LS: A review of the management of thoracolumbar burst fractures. Surg Neurol 67:221-231, 2007

9. Das K, Couldwell WT, Sava G, Taddonio RF: Use of cylindrical titanium mesh and locking plates in anterior cervical fusion. Technical note. J Neurosurg 94(1 Suppl):174-178, 2001

10. Davis CM 3rd, Berry DJ, Harmsen WS: Cemented revision of failed uncemented femoral components of total hip arthroplasty. J Bone Joint Surg Am 85-A(7):1264-1269, 2003

11. Denis $F:$ The three column spine and its significance in the classification of acute thoracolumbar spinal injuries. Spine 8:817-831, 1983

12. Dvorak MF, Kwon BK, Fisher CG, Eiserloh-HL 3rd, Boyd M, Wing PC: Effectiveness of titanium mesh cylindrical cages in anterior column reconstruction after thoracic and lumbar vertebral body resection. Spine 28:902-908, 2003

13. Eck KR, Bridwell KH, Ungacta FF, Lapp MA, Lenke LG, Riew KD: Analysis of titanium mesh cages in adults with minimum twoyear follow-up. Spine 25:2407 - 2415, 2000

14. Eck KR, Lenke LG, Bridwell KH, Gilula LA, Lasgari CJ, Riew KD: Radiographic assessment of anterior titanium mesh cages. J Spinal Disord 13:501-510, 2000

15. Hamburger C, Festenberg FV, Uhl E: Ventral discectomy with PMMA interbody fusion for cervical disc disease: Long-term results in 249 patients. Spine 26:249-255, 2001

16. Kaneda K, Taneichi H, Abumi K, Hashimoto T, Satoh S, Fujiya $\mathrm{M}$ : Anterior decompression and stabilization with the Kaneda device for thoracolumbar burst fractures associated with neurological deficits. J Bone Joint Surg Am 79:69-83, 1997
17. Kurz LT, Garfin SR, Booth RE Jr: Harvesting autogenous iliac bone grafts: A review of complications and techniques. Spine 14:1324-1331, 1989

18. Malinin TI, Brown MD: Bone allografts in spinal surgery. Clin Orthop 154:68-73, 1981

19. McDonough PW, Davis R, Tribus C, Zdeblick TA: The management of acute thoracolumbar burst fractures with anterior corpectomy and Z-plate fixation. Spine 29: 1901-1909, 2004

20. Pan HC, Wang YC, Lee $\mathrm{CH}$, Yang DY: Hollow bone cement filled with impacted cancellous bone as a substitute for bone grafts in cervical spine fusion. J Clin Neurosci 14(2):143-147, 2007

21. Prolo DJ, Oklund SA: Posterior and posterolateral spinal fusions using ethylene oxide sterilized cancellous allograft. Spine May 16(5):600-601, 1991

22. Robertson PA, Rawlinson HJ, Hadlow AT: Radiologic stability of titanium mesh cages for anterior spinal reconstruction following thoracolumbar corpectomy. J Spinal Disord Tech 17:44-52, 2004

23. Siebenga J, Leferink VJ, Segers MJ, Elzinga MJ, Bakker FC, Haarman HJ, Rommens PM, ten Duis HJ, Patka P: Treatment of traumatic thoracolumbar spine fractures: A multicenter prospective randomized study of operative versus nonsurgical treatment. Spine 31:2881-2890, 2006

24. Tropiano P, Huang RC, Louis CA, Poitout DG, Louis RP: Functional and radiographic outcome of thoracolumbar and lumbar burst fractures managed by closed orthopaedic reduction and casting. Spine 28:2459-2465, 2003

25. Vaccaro AR, Kim DH, Brodke DS, et al: Diagnosis and management of thoracolumbar spine fractures. J Bone Joint Surg Am 85:2456-2470, 2003

26. Van den Bent MJ, Oosting J, Wouda EJ, Van Acker EH, Ansink BJ, Braakman R: Anterior cervical discectomy with or without fusion with acrylate: A randomized trial. Spine 21:834-840, 1996

27. van der Roer N, de Lange ES, Bakker FC, de Vet HC, van Tulder MW.: Management of traumatic thoracolumbar fractures: A systematic review of the literature. Eur Spine J 14:527-534, 2005

28. Verlaan JJ, Diekerhof $\mathrm{CH}$, Buskens $\mathrm{E}$, van der Tweel I, Verbout AJ, Dhert WJ, Oner FC: Surgical treatment of traumatic fractures of the thoracic and lumbar spine: A systematic review of the literature on techniques, complications, and outcome. Spine 29:803-814, 2004

29. Wang $X Y$, Dai LY, Xu HZ, Chi YL: Kyphosis recurrence after posterior short-segment fixation in thoracolumbar burst fractures. J Neurosurg Spine 8:246-254, 2008

30. Watts NB, Harris ST, Genant HK: Treatment of painful osteoporotic vertebral fractures with percutaneous vertebroplasty or kyphoplasty. Osteoporosis Int 12:429-437, 2001

31. Willen J, Anderson J, Toomoka K, Singer K: The natural history of burst fractures at the thoracolumbar junction. J Spinal Disord 3:39-46, 1990

32. Wood KB, Bohn D, Mehbod A: Anterior versus posterior treatment of stable thoracolumbar burst fractures without neurologic deficit: A prospective, randomized study. J Spinal Disord Tech 18(suppl):S15-23, 2005 